\title{
WATER EROSION IN EUCALYPTUS FOREST IN THE MUNICIPALITY OF OTACÍLIO COSTA (SC)
}

\author{
Gilmar Souza Pereira ${ }^{2} \quad$,Ildegardis Bertol ${ }^{3 *}$ (), Bruno Afonso Magro ${ }^{4} \quad$, Ariane Andreola ${ }^{3} \odot$, and \\ Bárbara Bagio ${ }^{3} \mathrm{CC}$
}

\footnotetext{
${ }^{1}$ Received on 19.09.2019 accepted for publication on 18.02.2020.

${ }^{2}$ Universidade do Planalto Catarinense, Bionature Soluções Ambientais, Lages, SC- Brasil. E-mail: < gilsp02@gmail.com>.

${ }^{3}$ Universidade do Estado de Santa Catarina, Departamento de Solos, Lages, SC- Brasil. E-mail: <ildegardis.bertol@udesc.br>, <ariandreola@yahoo.com.br>and <barbarabagio@yahoo.com.br>.

${ }^{4}$ Universidade Federal do Paraná, Programa de Pós-Graduação em Engenharia Florestal, Curitiba, PR- Brasil. E-mail: <bruno.magro@ yahoo.com.br>.

*Corresponding author.
}

\begin{abstract}
Water erosion is the main factor of degradation and reduction of the productive capacity of the soil, requiring management operations that minimize water and soil losses and at the same time maximize crop productivity. The research aimed to quantify losses by water erosion and, in the runoff water, determine the levels and total losses of $\mathrm{P}$ and $\mathrm{K}$ during the development of Eucalyptus (Eucalyptus benthamii). Eucalyptus was planted in three types of soil preparation: minimum preparation in the direction of the slope, minimum preparation in the contour of the slope, and semi-mechanized preparation, in an experiment in southern Brazil on a Haplic Dystrudept soil. We observed that the mechanical preparation of the soil carried out in the direction of the slope is less effective in controlling soil losses than the mechanical carried out perpendicularly to the slope and also less effective than the manual in pits, in which the soil losses are equivalent to $10 \%$ of those that occur in the direction of the slope. As for the control of water losses, manual preparation in pits is more effective than the two mechanized preparations. The greatest losses of soil occur in the fall, with losses 27 times greater in relation to the other seasons of the year, and the greatest losses of water occurred in the mechanized preparation perpendicular to the slope and in the manual preparation. Water losses vary less than soil losses, regardless of the type of soil preparation and the season. The losses of phosphorus and potassium by the Runoff water vary with the contents in the soil, with the type of soil preparation and with the moment of evaluation.

Keywords: Soil management, Water and soil losses, Silviculture.
\end{abstract}

\section{EROSÃO HÍDRICA EM FLORESTA DE EUCALIPTO NO MUNICÍPIO DE OTACÍLIO COSTA (SC)}

RESUMO - A erosão hídrica é o principal fator de degradação e redução da capacidade produtiva do solo, exigindo operações de manejo que minimizem as perdas de água e solo e ao mesmo tempo maximizem a produtividade da cultura. Com a pesquisa objetivou-se quantificar as perdas por erosão hídrica e, na água de enxurrada, determinar os teores e as perdas totais de P e K durante o desenvolvimento de eucalipto (Eucalyptus benthamii). O eucalipto foi plantado em três tipos de preparo do solo: mecanizado em sulcos na direção do declive (PMD); mecanizado em sulcos perpendiculares ao declive (PMC); e cova individual para cada planta (PSC), em um experimento no sul do Brasil sobre um Cambissolo Háplico. Observamos que o preparo mecânico do solo realizado na direção do declive é menos eficaz no controle das perdas de solo do que o mecânico realizado perpendicularmente a declive e do que o manual em covas, nos quais as perdas de solo equivalem a $10 \%$ daquelas que ocorrem na direção do declive. Quanto ao controle das perdas de água, o preparo manual em covas é mais eficaz do que os dois preparos mecanizados. As maiores perdas de solo ocorrem no outono, com perdas 27 vezes maiores em relação às outras estações do ano, e as maiores perdas de água ocorreram no preparo mecanizado perpendicularmente ao declive e no preparo manual. As perdas de água variam menos do que as perdas de solo, independentemente do tipo de preparo de solo e da estação do ano. As perdas de fósforo e

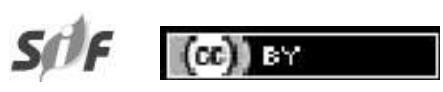

Revista Árvore 2020;44:e4419 http://dx.doi.org/10.1590/1806-908820200000019 


\begin{abstract}
potássio pela água de enxurrada variam com os teores no solo, com o tipo de preparo do solo e com o momento de avaliação.
\end{abstract}

Palavras-Chave: Manejo do solo, Perdas de água e solo, Silvicultura.

\section{INTRODUCTION}

Rainwater erosion in the soil is influenced by the type of rain, soil, relief, cover and soil management and use of conservation practices (Wischmeier and Smith, 1978). The phenomenon of soil erosion occurs in three distinct phases, disaggregation, transport and deposition of particles, concomitantly and progressively (Ellison, 1944). Rainwater erosion is caused by the effect of the impact of raindrops combined with the surface runoff of water (Foster, 1982). Induced erosion impoverishes the soil in its place of origin and contaminates the environment, especially the water, outside the place of origin of the erosion (Sharpley et al., 1982).

Vegetation cover and soil management are the main factors that affect rainwater erosion, so that in crops with forests (Magro et al., 2011), pastures (Inácio et al., 2007) and agricultural species (Schick et al., 2017; Bandeira et al., 2019) erosion is influenced by the type of plant, type and amount of plant residue on the surface and type, manner and intensity of mechanical soil preparation. In a planted forest, the variables that influence erosion are the type, density, and age of the plants and the manner of soil preparation during planting, under conditions of equal rainfall, soil, and relief (Magro et al., 2011).

The forest cover modifies the movement and the amount of water in several processes of the hydrological cycle, one of the main modifications occurring in the interception by the canopy of the plants, in the infiltration of water in the soil and the surface runoff (Arcova et al., 2003; Oliveira et al., 2014). Soil preparation carried out in contour (in relation to the slope) decreases soil losses by approximately $50 \%$ compared to the downhill preparation, while water losses are less reduced than soil losses, regardless of the type of cultivation (Wischmeier and Smith, 1978; Luciano et al., 2009) and, therefore, contour cultivation presents itself as an important conservation practice.

Losses of plant nutrients due to water erosion impoverish the soil, decrease the productive capacity of the soil and reflect on production costs (Bertol et al., 2017). According to these authors, these losses depend on the contents of nutrients present in the soil, the amounts of fertilizer added and the total losses of water and soil by erosion. Normally, there is a positive relationship between nutrient losses due to erosion and the contents on the soil surface (Barbosa et al., 2009).

With the present work, we aim to quantify the losses of water and soil and phosphorus and potassium in the water from runoff by erosion, in eucalyptus forestation during the third and fourth year, after planting in three different forms of soil management.

\section{MATERIAL AND METHODS}

The work was carried out in the Planalto Serrano Catarinense region, in a Haplic Dystrudept, classified according to criteria Soil Survey Staff (2014), with local coordinates of $\mathrm{W} 50^{\circ} 05$ 'and $\mathrm{S} 27^{\circ} 33^{\prime}$, at an average altitude of $841 \mathrm{~m}$. The region's climate is $\mathrm{Cfb}$, according to the Köppen classification, with an annual rainfall of $1,533 \mathrm{~mm}$ (Schick et al., 2014). In the 0-20 cm layer, the soil had 3.9 and $31 \mathrm{mg} \mathrm{dm}^{-3}$ of phosphorus (P) and potassium (K), 1.1 and $0.8 \mathrm{cmolc} \mathrm{dm}^{-3}$ of calcium (Ca) and magnesium $(\mathrm{Mg}), 4.7 \%$ organic matter $(\mathrm{OM})$ and $340,189,234$ and $237 \mathrm{~g} \mathrm{~kg}^{-1}$ of clay, coarse sand, fine sand, and silt, respectively; in the $20-40 \mathrm{~cm}$ layer, the levels were 1.2 and $21 \mathrm{mg} \mathrm{dm}^{-3}, 1.0$ and $0.7 \mathrm{cmolc} \mathrm{dm}^{-3}$, $3,7 \%$, and $345,246,184$, and $225 \mathrm{~g} \mathrm{~kg}^{-1}$. The slope of the ground in the area of the experimental units is $14.8 \%$ in the average of the plots, having been cultivated pine (Pinus taeda) between 1962 and 2009 and, in 2009, the harvest was done, keeping part of the cultural remains in the soil.

The research started in 2009 after an initial soil preparation, in which $1 \mathrm{t} \mathrm{ha}^{-1}$ of dolomitic limestone was applied to the soil to increase its levels of calcium and magnesium. The limestone was incorporated with one plow and two harrows. Following the application of lime, soil preparation was carried out in three forms, distributed with three repetitions, totaling nine plots, where: treatment 1: mechanized subsoiling carried out parallel to the slope, with the aid of subsoiler, with furrows $2.5 \mathrm{~m}$ apart from each other, totaling five furrows per plot, here called "minimum preparation in the

Revista Árvore 2020;44:e4419 
direction of the slope" (MPD); treatment 2: mechanized subsoiling carried out across the slope, with aid of a subsoiler, with furrows $2.5 \mathrm{~m}$ apart from each other, totaling nine furrows per parcel, here called "minimum preparation in the contour of the slope" (MPC); treatment 3: manually opened pits with the aid of a hoe, $2.5 \mathrm{~m} \mathrm{x}$ $2.5 \mathrm{~m}$ apart from each other, called "semi-mechanized preparation" (SMP). Following the preparation of the soil, still in 2010, eucalyptus (Eucaliptus benthamii) was planted, in which the trees were $2.5 \mathrm{~m}$ apart from each other, totaling 45 trees per plot.

At the time of planting of eucalyptus, the following basic fertilization was applied to the soil: $0.15 \mathrm{~kg}$ of NPK fertilizer (06-30-06) in each plant, divided and applied in two side pits with $0.075 \mathrm{~kg}$ each. The side pits were opened $10 \mathrm{~cm}$ away from the seedling, on opposite sides, with the fertilizer in a column with a depth between 3 $\mathrm{cm}$ and $11 \mathrm{~cm}$ below the soil surface. The first cover fertilization was carried out in April 2010, with $0.2 \mathrm{~kg}$ of NPK fertilizer (10-05-20) in each plant, distributed on the soil surface within the canopy projection and without incorporation. The second cover fertilization was carried out in October of the same year, identical to the first in quantity, formulation and application form. So, in this cultivation phase, a total of, $78 \mathrm{~kg} \mathrm{ha}^{-1}$ of $\mathrm{N}, 104 \mathrm{~kg} \mathrm{ha}^{-1}$ of $\mathrm{P}_{2} \mathrm{O}_{5}$ and $142 \mathrm{~kg} \mathrm{ha}^{-1}$ of $\mathrm{K}_{2} \mathrm{O}$ were added.

Immediately after correcting and fertilizing the soil and planting the eucalyptus, experimental units (plots) were installed, arranged side by side, with dimensions of $12 \mathrm{~m} \mathrm{x} 24 \mathrm{~m}$ each $\left(288 \mathrm{~m}^{2}\right)$, with the largest length in the direction of the slope (Magro et al, 2011). For the delimitation of the contour, galvanized sheets $40 \mathrm{~cm}$ high were used, driven $20 \mathrm{~cm}$ in the ground. In the lower base of the plots, $60 \mathrm{~cm}$ high plates were used, driven 40 $\mathrm{cm}$ into the soil, arranged in a "V" shape to collect and conduct the flow to the runoff storage tanks, positioned in the lowest part of the slope. For the collection of the flow two collection tanks with a capacity of 400 and 500 liters were used. The first (400L) was connected to the second tank $(500 \mathrm{~L})$ through a window contained in a "Geibb" type divider, with 13 outlets. The runoff water and sediments with a larger diameter and/or denser were stored in the first tank, with the second tank storing water and sediments of a smaller diameter and/or less dense. Then, the soil was fertilized with the commercial fertilizer formula NPK (10-5-20), in the amount of 0.2 $\mathrm{kg}$ plant $^{-1}$, or, $9 \mathrm{~kg} \mathrm{plot}^{-1}\left(312.5 \mathrm{~kg} \mathrm{ha}^{-1}\right)$, applied on the soil surface, manually by haul, in the same amount in all treatments.
The height of rain was measured by a PVC rain gauge with a catchment area of $314 \mathrm{~cm}^{2}$ and the reading was made weekly, after each rain event or accumulated rain during the week, at the same time as the runoff collection. A rain gauge was placed on a forest road beside the experiment to measure the effective rain and, in the treatments, a rain gauge was installed in each plot to measure the internal rain.

Runoff quantification was done after an individual or accumulated events occurred during the week, based on Wischmeier and Smith (1978). The height of the runoff blade, stored in each tank, was measured with the aid of a graduated ruler, whose value multiplied by the tank area resulted in the runoff volume. In the case of the second tank, the total runoff volume was obtained by multiplying the volume measured by 13 , due to the existence of the "Geibb" divider with 13 windows that allowed the passage of $1 / 13$ of the runoff from the first to the second tank. The monthly and annual water losses by runoff were obtained by adding the weekly runoff measured in the collection boxes of each treatment.

Surface runoff samples (water plus sediment) to determine soil and water losses, and trunk runoff, were collected in 17 opportunities during the research, on the following dates: in 2012: 06/17;06/18;06/27; $09 / 13 ; 09 / 25 ; 10 / 08 ; 10 / 30 ; 12 / 17$; and $12 / 24$; and in 2013: 02/08; 03/07; 03/25; 04/29; 06/04; 06/20; 07/05; and $07 / 13$. For the collection of runoff samples, the procedure described in (Bertol et al., 2017) was used, which consists of the homogenization of water and sediments contained in the tanks with the simultaneous removal of three samples of $300 \mathrm{~mL}$ each. Two samples per tank were collected to quantify the runoff and, thus, calculate the losses of water and soil, and one per tank to determine the content of nutrients, using bottles of 300 $\mathrm{mL}$.

With the runoff samples, we determined the water and soil losses following the procedure described in Bandeira et al. (2019). Due to the slope variation between the plots, the observed soil loss data were adjusted for the average slope of the area of the plots, using the terrain slope factor (factor S) of the Universal Soil Loss Equation (USLE), according to the procedure recommended by Wischmeier and Smith (1978).

Soil samples were collected for chemical analysis in the superficial layer $(0-20 \mathrm{~cm})$, in three moments: after the beginning of the research, shortly after
Revista Árvore 2020;44:e4419 
fertilization and shortly after the end of the research. They were collected in three positions in each plot: two meters below the upper end, in the intermediate position and two meters above the lower end. In each position, a sample was collected inside the line and under the plant, and another, in the interval between the lines. For each plot, these samples were mixed, making a single composite sample. The levels of available phosphorus (P), exchangeable potassium (K) and organic matter $(\mathrm{OM})$ were determined. The evaluation of $\mathrm{P}$ and $\mathrm{K}$ losses in the runoff water was done in two periods, before and after fertilization. In each period, the samples were stored in a refrigerator, at $2^{\circ} \mathrm{C}$, until the completion of collections and, in the end, a single sample was composed in which the levels of phosphorus and potassium in soluble form were determined, as well as the content of OM, in accordance with Tedesco et al. (1995). The total losses of $\mathrm{P}$ and K were calculated by multiplying the water content by the volume of water loss by erosion.

The effect of the treatments was analyzed using the residual variance, with the application of the Tukey test $(p \leq 0.05)$ for the comparison of means whenever there was a difference between them, considering that the treatments were distributed entirely at random, using the software Assistat 7.7 Beta (Silva and Azevedo, 2016).

\section{RESULTS}

The height of indoor rain in the forest $\left(\mathrm{R}_{\text {in }}\right)$ was explained in $99 \%$ of the cases by the effective rain height $\left(\mathrm{R}_{\mathrm{ef}}\right)$, with excellent adjustment (Figure 1), despite the wide variation between these two types of rain commonly occurring in forest areas. The annual height of $R_{\text {in }}$ in general, varied little from one plot to another in the research, within each season of the year, meaning little influence on surface runoff.

The total annual water losses (WL) per runoff (Table 1) were low in relation to the height of rain, and less than those that occurred in previous periods of time in the same experiment. At those times, values of up to $3 \%$ and $14 \%$ of the rainfall volume were verified in the first and second years of the research, respectively. In plot 7 (MPC), for example, there was a numerically higher $\mathrm{R}_{\text {in }}$ than in other plots, with the exception of winter, totaling a difference of $125 \mathrm{~mm}$ in the year compared to plot 9 (SMP), where the lowest height occurred. Clearly, the $\mathrm{R}_{\text {in }}$ was greater in autumn and spring than in other seasons, whose greatest heights occurred in October of the first

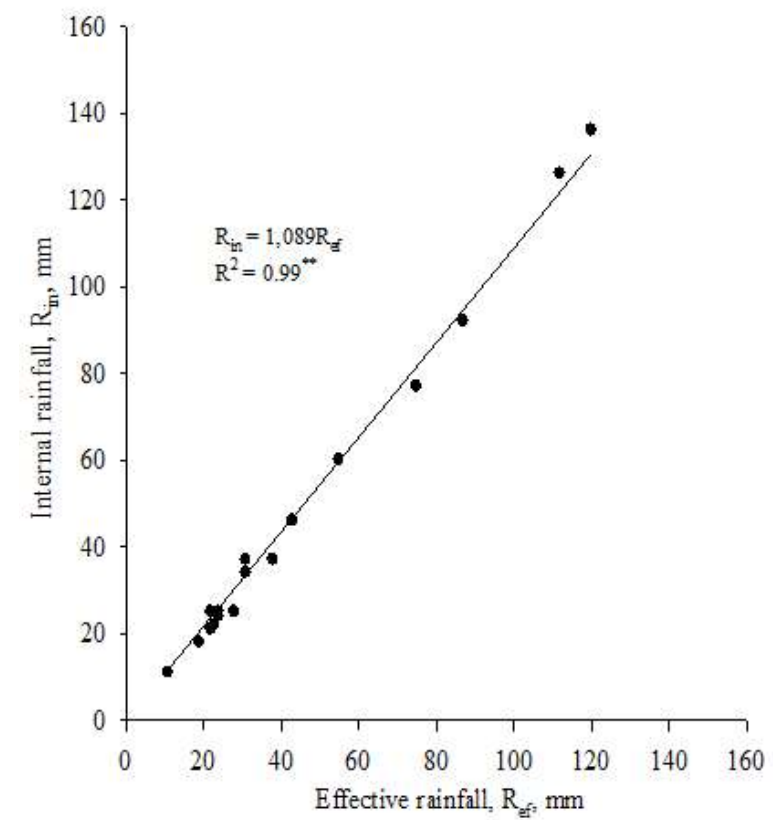

Figure 1 - Relationship between height of indoor rain in the forest $\left(R_{i n}\right)$ and effective rain height (Ref) in the experimental area (average of repetitions).

Figura 1 - Relação entre altura de chuva interna $\left(C_{i n}\right)$ e de chuva efetiva $\left(C_{e}\right)$ na área experimental (média das repetições).

year and March of the second year. The total annual soil losses (SL) by water erosion were low compared to those found in the second year of cultivation and, even more so, in the first year.

The height of $\mathrm{R}_{\text {in }}$ and the WL and SL varied between seasons, in each treatment, with the highest values having occurred in general in autumn (Table 2). For $R_{\text {in, }}$, the lowest values occurred in winter, while for WL and SL the lowest values ranged between winter, spring, and summer.

The contents of $\mathrm{P}$ in the soil were not influenced by the treatments in any of the evaluation periods, while those of $\mathrm{K}$ and $\mathrm{OM}$ were influenced before the application of the fertilizer in the soil (Table 3). P is influenced by the residual tillage effect, as it is an element little mobile in the soil. Before fertilizer application, the $\mathrm{K}$ content in the soil was $22 \%$ higher in the MPC treatment than in the others, while the OM was $22 \%$ higher in the SMP than in the others. $\mathrm{K}$ and OM are dynamic elements, which can easily vary according to the type of mechanical mobilization and with the water erosion that moves sediments on the soil surface.

Revista Árvore 2020;44:e4419 
Table 1 - Total effective rain $\left(\mathrm{T}_{\mathrm{er}}\right)$ and internal rain in each replicate (1 .. 9), by season (Sea), and total effective rain and total water and soil losses, per year, in the three treatments in Haplic Dystrudept soil.

Tabela 1 - Chuva efetiva $\left(C_{e}\right)$ total e chuva interna em cada repetição (1...9), por estação do ano (Est), e chuva efetiva total e perdas totais de água e solo, por ano, nos três tratamentos em um Cambissolo Háplico Alítico.

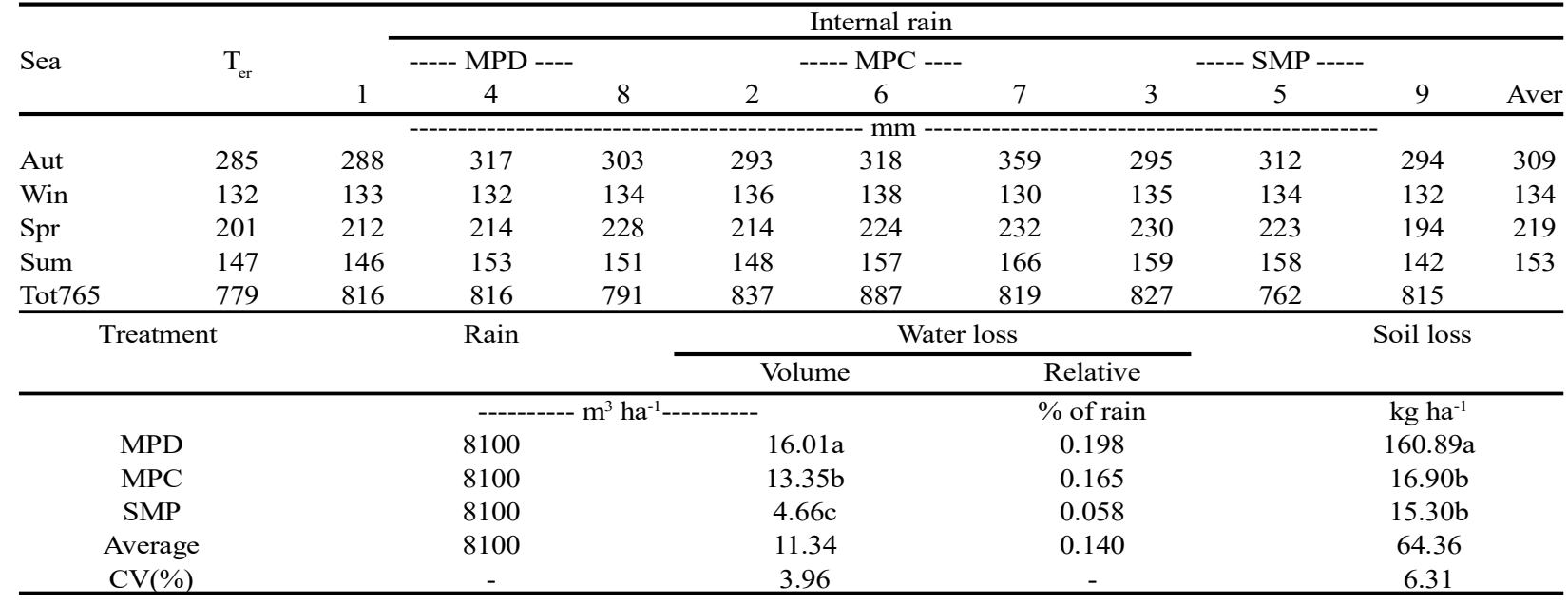

MPD: minimum preparation in the direction of the slope; MPC: minimum preparation in the contour of the slope; SMP: semi-mechanized preparation. Aver: average. CV: coefficient of variation. Aut.: Autumn; Win.: Winter; Spr.: Spring; Sum.: Summer; Tot.: total.

PMD: preparo mecanizado na direção do declive; PMC: preparo mecanizado em contorno no declive; PSM: preparo semi-mecanizado. Med: média. CV: coeficiente de variação. Out: outono; Inv: inverno; Pri: primavera; Ver: verão; Tot: total.

The contents of $\mathrm{P}$ in the runoff water were equivalent to only $3.5 \%$ of those existing in the soil, in the average of the treatments, the times of collection of the samples and the positions in the plots, while the levels of $\mathrm{K}$ were equivalent to $17 \%$ (Table 4 ). In the case of $P$, this is due to the low solubility in water, while in the case of $\mathrm{K}$, to the high solubility in water. The levels of $\mathrm{P}$ and $\mathrm{K}$ tended to increase in the runoff water, comparing before and after fertilization was done in most treatments, due to the addition of these elements to the soil in the form of fertilizer.

The total losses of $\mathrm{P}$ were low compared to those that normally occur in agricultural cultivation areas on plot-scale, varying between 1.12 and $3.07 \mathrm{~g} \mathrm{ha}^{-1}$ (Table 4). Even so, they cannot be disregarded, particularly because of the eutrophic effect that this element has if it is stored in an aquatic environment. In the case of $\mathrm{K}$, total losses can be considered high, whose values varied

Table 2 - Internal rain and soil and water losses, for each season (Sea) of the year, in three treatment (Treat) in a Haplic Dystrudept soil. Tabela 2 - Chuva interna e perdas de água e solo, por estação do ano, nos três tratamentos em um Cambissolo Háplico Alítico.

\begin{tabular}{|c|c|c|c|c|c|c|c|c|c|c|c|c|}
\hline \multirow{2}{*}{$\begin{array}{l}\text { Treat } \\
\text { Sea }\end{array}$} & \multicolumn{4}{|c|}{ MPD } & \multicolumn{4}{|c|}{ MPC } & \multicolumn{4}{|c|}{ SMP } \\
\hline & \multicolumn{2}{|l|}{ Rain } & WL & SL & Rain & \multicolumn{2}{|c|}{ WL } & SL & \multicolumn{2}{|l|}{ Rain } & WL & SL \\
\hline & \multicolumn{2}{|l|}{$\mathrm{mm}$} & $\%$ & $\mathrm{~kg} \mathrm{ha}^{-1}$ & $\mathrm{~mm}$ & \multicolumn{2}{|c|}{$\%$} & $\mathrm{~kg} \mathrm{ha}^{-1}$ & \multicolumn{2}{|l|}{$\mathrm{mm}$} & $\%$ & $\mathrm{~kg} \mathrm{ha}^{-1}$ \\
\hline Autumn & \multicolumn{2}{|l|}{$303 a$} & $1.26 \mathrm{a}$ & $150.9 a$ & $323 a$ & \multicolumn{2}{|c|}{$0.84 \mathrm{ab}$} & $11.8 \mathrm{a}$ & \multicolumn{2}{|l|}{$300 \mathrm{a}$} & $0.39 \mathrm{a}$ & $11.1 \mathrm{a}$ \\
\hline Winter & \multicolumn{2}{|l|}{$133 d$} & $0.86 b$ & $1.0 \mathrm{c}$ & $135 d$ & \multicolumn{2}{|c|}{$0.95 a$} & $1.5 b$ & \multicolumn{2}{|l|}{$134 d$} & $0.09 \mathrm{c}$ & $0.1 \mathrm{c}$ \\
\hline Spring & \multicolumn{2}{|l|}{$218 b$} & $0.70 \mathrm{c}$ & $1.9 \mathrm{c}$ & $223 b$ & \multicolumn{2}{|c|}{$0.59 \mathrm{c}$} & $2.0 \mathrm{~b}$ & \multicolumn{2}{|l|}{$216 b$} & $0.25 b$ & $2.3 b$ \\
\hline Summer & \multicolumn{2}{|l|}{$150 \mathrm{c}$} & $0.73 c$ & $7.1 \mathrm{~b}$ & $157 \mathrm{c}$ & \multicolumn{2}{|c|}{$0.72 b c$} & $1.6 b$ & \multicolumn{2}{|l|}{$153 \mathrm{c}$} & $0.42 \mathrm{a}$ & $1.8 \mathrm{~b}$ \\
\hline CV $(\%)$ & \multicolumn{2}{|l|}{1,7} & 5.07 & 3.1 & 2.5 & \multicolumn{2}{|c|}{6.70} & 10.0 & \multicolumn{2}{|l|}{2.4} & 9.04 & 5.9 \\
\hline Sea & \multicolumn{3}{|c|}{ Sutumn } & \multicolumn{3}{|c|}{ Winter } & \multicolumn{3}{|c|}{ Spring } & \multicolumn{3}{|c|}{ Summer } \\
\hline Trat & Rain & $\mathrm{WL}$ & $\mathrm{SL}$ & Rain & WL & $\mathrm{SL}$ & Rain & WL & $\mathrm{SL}$ & Rain & WL & $\mathrm{SL}$ \\
\hline & $\mathrm{mm}$ & $\%$ & $\mathrm{~kg} \mathrm{ha} \mathrm{h}^{-1}$ & $\mathrm{~mm}$ & $\%$ & $\mathrm{~kg} \mathrm{ha}^{-1}$ & $\mathrm{~mm}$ & $\%$ & $\mathrm{~kg} \mathrm{ha}{ }^{-1}$ & $\mathrm{~mm}$ & $\%$ & $\mathrm{~kg} \mathrm{ha}^{-1}$ \\
\hline MPD & $303 b$ & $1.26 \mathrm{a}$ & $150.9 a$ & 133 & $0.86 a$ & $1.0 \mathrm{~b}$ & 218 & $0.70 \mathrm{a}$ & 1.9 & 150 & $0.73 a$ & $7.1 \mathrm{a}$ \\
\hline MPC & $323 a$ & $0.84 b$ & $11.8 \mathrm{~b}$ & 135 & $0.95 a$ & $1.5 \mathrm{a}$ & 223 & $0.59 b$ & 2.0 & 157 & $0.72 \mathrm{a}$ & $1.6 b$ \\
\hline SMP & $300 \mathrm{~b}$ & $0.39 \mathrm{c}$ & $11.1 \mathrm{~b}$ & 134 & $0.09 \mathrm{~b}$ & $0.1 \mathrm{c}$ & 216 & $0.25 \mathrm{c}$ & 2.3 & 153 & $0.42 b$ & $1.8 \mathrm{~b}$ \\
\hline $\mathrm{CV}(\%)$ & 1.1 & 4.70 & 2.6 & 4.3 & 6.90 & 13.4 & 2.3 & 7.20 & 10.8 & 2.3 & 7.90 & 6.2 \\
\hline
\end{tabular}

MPD: minimum preparation in the direction of the slope; MPC: minimum preparation in the contour of the slope; SMP: semi-mechanized preparation. Treat: treatment.Aver: average. CV: coefficient of variation.

PMD: preparo mecanizado na direção do declive; PMC: preparo mecanizado em contorno no declive; PSM: preparo semi-mecanizado. Trat: tratamento. Med: média. CV: coeficiente de variação. 
Table 3 - Phosphorus $(\mathrm{P})$, potassium $(\mathrm{K})$ and organic matter $(\mathrm{OM})$ contents determined in the $0-20 \mathrm{~cm}$ layer of soil before applying the fertilizer, after applying the fertilizer and at the end of the research, in the three treatment (Treat) in a Haplic Dystrudept soil.

Tabela 3 - Teores de fósforo (P), potássio $(K)$ e matéria orgânica $(M O)$ determinados na camada de 0-20 cm do solo antes de aplicar o adubo, logo após a aplicar o adubo e ao final da pesquisa, nos três tratamentos em um Cambissolo Háplico.

\begin{tabular}{|c|c|c|c|c|c|c|c|c|c|}
\hline \multirow{2}{*}{$\begin{array}{l}\text { Date } \\
\text { Treat }\end{array}$} & \multicolumn{3}{|c|}{ Before applying the fertilizer } & \multicolumn{3}{|c|}{ After applying the fertilizer } & \multicolumn{3}{|c|}{ End of the research } \\
\hline & $\mathrm{P}$ & $\mathrm{K}$ & $\mathrm{OM}$ & $\mathrm{P}$ & $\mathrm{K}$ & $\mathrm{OM}$ & $\mathrm{P}$ & $\mathrm{K}$ & $\mathrm{OM}$ \\
\hline & \multicolumn{2}{|c|}{$\mathrm{mg} \mathrm{dm}^{-3}$} & $\%$ & \multicolumn{2}{|c|}{$\mathrm{mg} \mathrm{dm}^{-3}$} & $\%$ & \multicolumn{2}{|c|}{$\mathrm{mg} \mathrm{dm}^{-3}$} & $\%$ \\
\hline MPD & 6.01 & $76 b$ & $7.5 \mathrm{~b}$ & 8.22 & 93 & 5.6 & 5.90 & 119 & 6.7 \\
\hline MPC & 6.67 & $89^{\mathrm{a}}$ & $7.4 \mathrm{~b}$ & 7.80 & 92 & 5.8 & 4.38 & 121 & 6.2 \\
\hline SMP & 6.94 & $70 b$ & $9.1 \mathrm{a}$ & 8.18 & 83 & 7.8 & 4.08 & 109 & 7.0 \\
\hline Average & 6.54 & 78 & 8.0 & 8.01 & 89 & 6.4 & 4.79 & 116 & 6.6 \\
\hline $\mathrm{CV}(\%)$ & 6.06 & 5.8 & 4.3 & 5.09 & 4.8 & 9.3 & 1.70 & 5.8 & 4.7 \\
\hline Treat & \multicolumn{3}{|c|}{ MPD } & \multicolumn{3}{|c|}{ MPC } & \multicolumn{3}{|c|}{ SMP } \\
\hline \multirow[t]{2}{*}{ Date } & $\mathrm{P}$ & $\mathrm{K}$ & $\mathrm{OM}$ & $\mathrm{P}$ & $\mathrm{K}$ & $\mathrm{OM}$ & $\mathrm{P}$ & $\mathrm{K}$ & $\mathrm{OM}$ \\
\hline & \multicolumn{2}{|c|}{$\mathrm{mg} \mathrm{dm}^{-3}$} & $\%$ & \multicolumn{2}{|c|}{$\mathrm{mg} \mathrm{dm}{ }^{-3}$} & $\%$ & \multicolumn{2}{|c|}{$\mathrm{mg} \mathrm{dm}^{-3}$} & $\%$ \\
\hline$\overline{\text { Before }}$ & $6.01 \mathrm{~b}$ & $76 \mathrm{c}$ & $7.5 \mathrm{a}$ & $6.67 \mathrm{a}$ & $89 b$ & $7.4 a$ & $6.94 \mathrm{~b}$ & $70 b$ & $9.1 \mathrm{a}$ \\
\hline After & $8.22^{\mathrm{a}}$ & $93 b$ & $5.6 \mathrm{c}$ & $7.80 \mathrm{a}$ & $92 b$ & $5.8 \mathrm{~b}$ & $8.18 \mathrm{a}$ & $83 b$ & $7.8 \mathrm{~b}$ \\
\hline End & $5.90 \mathrm{~b}$ & $119^{\mathrm{a}}$ & $6.7 \mathrm{~b}$ & $4.38 \mathrm{~b}$ & $121 \mathrm{a}$ & $6.2 \mathrm{ab}$ & $4.08 \mathrm{c}$ & $109 \mathrm{a}$ & $7.0 \mathrm{~b}$ \\
\hline Average & 6.71 & 96 & 6.6 & 6.28 & 101 & 6.5 & 6.40 & 87 & 8.0 \\
\hline $\mathrm{CV}(\%)$ & 2.73 & 5.0 & 3.4 & 8.21 & 5.8 & 7.8 & 2.81 & 6.0 & 6.4 \\
\hline
\end{tabular}

ment. Aver: average. CV: coefficient of variation.

PMD: preparo mecanizado na direção do declive; PMC: preparo mecanizado em contorno no declive; PSM: preparo semi-mecanizado. Trat: tratamento. Med: média. CV: coeficiente de variação.

between 51 and $320 \mathrm{~g} \mathrm{ha}^{-1}$, characterizing, thus, strong tendency of soil impoverishment caused by the export of this element via water erosion.

\section{DISCUSSION}

The spatial variability of $\mathrm{R}_{\text {in }}$ height in tropical forests is considered normal due to the punctuality of the collections, as verified by Amaral et al. (2013). These authors also observed that $\mathrm{R}_{\text {in }}$ was, at times, greater than Ref, due to the funneling effect of the vegetation, due to the diameter of the treetops, the opening of the foliage within the canopy and the space between trees. In the present study, differences in crown diameter and leaf opening within the crowns were observed (data not quantified). The higher $\mathrm{R}_{\text {in }}$ values in the autumn are explained by the general climatic condition of the region, which favors high-intensity and high-volume rainfall in this season, while the lower values are explained in part by the general climate of the region (Schick et al., 2014) and, in part, by the particular climatic conditions that determined drought during the research period.

The low WL in relation to the precipitated rain is due to the effect of the canopy of the plants, which promotes the interception of rainwater by the crown. The vegetal mass on the soil (plant litter) promoted the superficial retention and facilitated the infiltration of water in the soil due to the galleries (observed, but not quantified) opened by the roots. The roots of the trees open galleries in the soil that constitute porosity and favor the infiltration of water in the soil (Oliveira et al., 2014).

The decrease in WL due to the surface runoff compared to what was verified by Magro et al (2011)

Table 4 - Total phosphorus and potassium contents and losses determined in runoff water samples before fertilization and after fertilization, in the three treatments in an Haplic Dystrudept soil.

Tabela 4 - Teores e perdas totais de fósforo e potássio determinados em amostras de água da enxurrada antes da adubação e após a adubação, nos três tratamentos em um Cambissolo Háplico Alítico.

\begin{tabular}{|c|c|c|c|c|}
\hline \multirow[t]{3}{*}{ Treatment } & \multicolumn{2}{|c|}{ Phosphorus Potassium } & \multicolumn{2}{|c|}{ Phosphorus Potassium } \\
\hline & \multicolumn{2}{|c|}{$---\mathrm{mg} \mathrm{L}^{-1}---$} & \multicolumn{2}{|c|}{$---\mathrm{g} \mathrm{ha}^{-1}---$} \\
\hline & \multicolumn{4}{|c|}{ Before fertilization } \\
\hline MPD & $0.13 b$ & $12 \mathrm{ab}$ & $2.08 \mathrm{~b}$ & $192 \mathrm{a}$ \\
\hline MPC & $0.23 \mathrm{a}$ & $15 \mathrm{a}$ & $3.07 \mathrm{a}$ & $200 \mathrm{a}$ \\
\hline SMP & $0.24 \mathrm{a}$ & $11 b$ & $1.12 \mathrm{c}$ & $51 b$ \\
\hline Average & 0.20 & 13 & 2.09 & 148 \\
\hline \multirow[t]{2}{*}{$\mathrm{CV}(\%)$} & 14.14 & 10.2 & 5.74 & 3.4 \\
\hline & \multicolumn{4}{|c|}{ After fertilization } \\
\hline$\overline{\mathrm{MPD}}$ & $0.14 b$ & $20 \mathrm{a}$ & $2.24 \mathrm{a}$ & $320 \mathrm{a}$ \\
\hline MPC & $0.19 b$ & $20 \mathrm{a}$ & $2.54 \mathrm{a}$ & $267 b$ \\
\hline SMP & $0.30 \mathrm{a}$ & $15 b$ & $1.40 \mathrm{~b}$ & $70 \mathrm{c}$ \\
\hline Average & 0.21 & 18 & 2.06 & 219 \\
\hline $\mathrm{CV}(\%)$ & 13.19 & 5.5 & 7.74 & 4.3 \\
\hline
\end{tabular}

preparation in the contour of the slope; SMP: semi-mechanized preparation. $\mathrm{CV}$ : coefficient of variation.

PMD: preparo mecanizado na direção do declive; PMC: preparo mecanizado em contorno no declive; PSM: preparo semi-mecanizado. CV: coeficiente de variação.

\section{Revista Árvore 2020;44:e4419}


and Padilha et al. (2017) is due to the growth of the forest that occurred during the research, increasing the litter biomass on the soil, the canopy of the treetops and the roots of the plants. The behavior of decreasing surface runoff over time in forest areas is also confirmed when comparing the values of this research with those obtained by Pires et al. (2006); Baptista and Levien (2010); Padilha et al. (2017) and Sun et al. (2018).

The total annual WL varied with the type of mechanized soil tillage that had been carried out three years before this study (Table 1), in agreement with Babtista and Levien (2010). In the mechanized preparation carried out in furrows along the slope (MPD), the WL were $20 \%$ higher than in the preparation carried out in contour to the slope (MPC) and, in the average of these two, 3.2 times greater than in the treatment in which soil preparation was done manually by individual pit (SMP). These results agree with Pires et al. (2006), who obtained higher values of water loss in eucalyptus planted along the slope with the burning of cultural remains. The lower WL in the SMP is explained by the smaller area of soil turned in this treatment, when compared with mechanized management (MPD and MPC). Magro et al. (2011) obtained WL values varying from 4 to $14 \%$ of the rainfall volume, while Padilha et al. (2017) obtained values varying from 2 to $3 \%$, in the same treatments. Although WL may seem low, still they cannot be disregarded, considering the importance of water in the soil for the life cycle of soil plants and organisms. This justifies the adoption of supportive conservation practices to hold these losses, storing runoff water within the cultivation area. In percentage terms, the total annual WLs showed very low values compared to the height of the rains, varying between $0.020 \%$ and $0.058 \%$, therefore, substantially lower than the WLs verified by Magro et al. (2011) and Padilha et al. (2017).

Magro et al. (2011) and Padilha et al. (2017) found SL values of up to $19,700 \mathrm{~kg} \mathrm{ha}^{-1}$ and $520 \mathrm{~kg}$ $\mathrm{ha}^{-1}$, respectively. The low SL values verified in this research are due to the same factors that contributed to the low WL, that is, the canopy of the plants, the vegetal mass in the form of litter and the galleries in the soil opened by the roots. These factors, taken as a whole, dissipate the kinetic energy of raindrops and, almost totally, the energy of the surface runoff, in addition to determining the increase of water infiltration in the soil and the reduction of the volume and speed of the runoff, as verified by (Pires et al., 2006; Baptista and Levien, 2010; Padilha et al., 2017).
The total annual SL were influenced by the way mechanized tillage was carried out three years before this survey (Table 1), in agreement with Babtista and Levien (2010). In the MPD treatment, the losses were 9.5 times greater than in the MPC, whose difference was determined by the direction of the soil tillage operation in relation to the slope, corroborating with data obtained by Pires et al. (2006). Thus, the preparation carried out in contour showed $90 \%$ effectiveness in reducing the SL compared to the preparation carried out along the slope, surpassing the effectiveness of the cultivation in contour carried out in areas of agricultural cultivation (Wischmeier and Smith, 1978; Luciano et al., 2009). The SMP treatment showed SL equal to that of MPC, differently from what happened with WL. Magro et al. (2011) obtained SL values varying numerically from 900 to $19,700 \mathrm{~kg} \mathrm{ha}^{-1}$ year $^{-1}$, while Padilha et al. (2017) obtained values varying from 70 to $520 \mathrm{~kg} \mathrm{ha}^{-1}$ year $^{-1}$ in the same treatments. Thus, it is possible to consider that the MPC and SMP are more soil conservationists than the MPD, although the losses seen in the latter have also been very low compared to those seen in previous years.

The higher height of $\mathrm{R}_{\text {in }}$ in autumn partially explains the higher WL and SL values in this season compared to the other seasons. The lower WL and SL occurred in the other seasons of the year are explained by the smaller consecutive $\mathrm{R}_{\text {in }}$, mainly in winter, and by the variation of water content in the soil that controlled the infiltration, especially in the spring and summer. These arguments were used by Oliveira et al. (2014) to justify the differences that occurred in these variables in their work carried out in pine reforestation.

Among the treatments, $\mathrm{R}_{\text {in }}$ varied in the fall, $\mathrm{WL}$ varied in the four seasons and SL varied in autumn, winter and summer (Table 2). The variation in $\mathrm{R}_{\text {in }}$ between treatments only in the autumn indicates that in this season of the year, probably the wind factor (not registered) influenced this spatial variation of rain more than in other seasons. It is also possible that the lower height of $\mathrm{R}_{\text {in }}$ in other seasons contributed to the lack of spatial variation between treatments. This lack of spatial variation in $\mathrm{R}_{\text {in }}$ did not influence $\mathrm{WL}$ which varied between treatments in all seasons of the year, due to the fact that WL are influenced by the infiltration of water into the soil, that depends on the initial conditions (Luciano et al., 2009; Oliveira et al., 2014). The variation in SL between treatments, which occurred in three of the four seasons, is explained by the same reasons that

Revista Árvore 2020;44:e4419 
determined the variation in WL, according to Magro et al. (2011) and Schick et al. (2014).

The contents of $\mathrm{P}$ and $\mathrm{K}$ in the soil tended to increase after the application of fertilizer in relation to the existing content in the initial phase of the experiment, while those of OM tended to decrease (Table 3 ). The increase in $\mathrm{P}$ and $\mathrm{K}$ occurred due to the direct effect of fertilization and, in the case of $\mathrm{K}$, also due to recycling by plants, which facilitated deposition on the surface due to the decomposition of plant biomass. The decrease in the levels of OM probably occurred due to effect of erosion, which carried it easily across the soil surface.

Comparing the levels of $\mathrm{P}$ in the runoff water between treatments, before fertilization, in the SMP content was $85 \%$ higher than in the MPD, while the K content was $8 \%$ lower (Table 4). After fertilization, the $\mathrm{P}$ content was 2.1 times higher in the SMP, while the K content was $25 \%$ lower. Thus, in the treatment that lost more water through runoff (MPD, also in MPC) there was a greater dilution effect for the case of $\mathrm{P}$ compared to the one that lost less water (SMP), in both collection periods, before and after the fertilizing. Regarding K, this dilution effect probably did not occur due to the high water solubility of this element compared to P.

Regarding the total losses of $\mathrm{P}$ and $\mathrm{K}$, erosion control is recommended to avoid, in the case of $\mathrm{P}$, the eutrophic effect of water sources and soil depletion at the place of erosion origin and, in the case of $\mathrm{K}$, the effect soil depletion. Although the total losses were not as high as those seen in agricultural areas, they are nevertheless worrying from the point of view of the financial cost of replacing nutrients.

\section{CONCLUSION}

The quantification of water erosion in eucalyptus cultivation, implanted in three types of soil preparation, allowed to conclude that the preparation carried out in the direction of the slope is less effective in controlling soil losses than the preparation perpendicular to the slope and manual in pits, in which soil losses are equivalent to $10 \%$ of those that occur in the direction of the slope. As to the control of water losses, manual preparation in pits is more effective, reducing them by $68 \%$ in relation to the two mechanized preparations.

The greatest losses of soil occur in the fall, with losses 27 times greater in relation to the other seasons of the year, for the mechanized tillage of the soil as well as for the manual one, being that in the autumn the greatest losses of water occur in the preparation perpendicular to the slope and in manual preparation. Water losses vary less than soil losses, regardless of the type of soil preparation and the season. The losses of the phosphorus and potassium nutrients by the runoff water vary with the contents existing in the soil and with the type of preparation, as well as with the moment if the evaluation is carried out before or after fertilization.

\section{REFERENCES}

Amaral LP, Ferreira RA, Watzlawick LF, Longhi SJ, Sebem E. Influência da floresta alterada na distribuição espacial de três espécies da Floresta Ombrófila Mista avaliada pela geoestatística. Revista Árvore. 2013;37(3):491-01. doi: 10.1590/S010067622013000300012

Arcova FCS, Cicco V, Rocha PAB. Precipitação efetiva e interceptação das chuvas por floresta de Mata Atlântica em uma microbacia experimental em cunha - São Paulo. Revista Árvore. 2003;27(2):257-62. doi:10.1590/S0100-67622003000200014

Bandeira DH, Bertol I, Vázquez EV, Ramos JC, Bertol C. Impact of pig slurry application on soil and water losses: Comparison with a historical series. Revista Brasileira de Engenharia Agrícola e Ambiental. 2019;23(6):425-31. doi: 10.1590/1807-1929

Baptista J, Levien R. Métodos de preparo de solo e sua influência na erosão hídrica e no acúmulo de biomassa da parte aérea de Eucaliptus Saligna em um cambissolo háplico da depressão central do Rio Grande do Sul. Revista Árvore. 2010;34(4):567-75. doi: 10.1590/ S0100-67622010000400001

Barbosa FT, Bertol I, Luciano RV, Gonzalez AP. Phosphorus losses in water and sediments in runoff of the water erosion in oat and vetch crops seed in contour and downhill. Soil Tillage Research. 2009;106(1):2228. doi:10.1016/j.still.2009.09.004

Bertol I, Luciano RV, Bertol C, Bagio B. Nutrient and Organic Carbon Losses, Enrichment Rate, and Cost of Water Erosion. Revista Brasileira de Ciência do Solo. 2017;41:01-15. doi: 10.1590/18069657rbcs20160150

Ellison WD. Some effects of raindrop erosion. 
Agricultural Engineering. 1947;25:131-136, 181-2.

Foster GR. Modeling the erosion processes. In: Haan CT, Johnson HP, Brakensiek DL, eds. Hydrological modeling of small wathersheds. American Society of Agricultural Engineers: St Joseph; 1982. p. 297-300.

Inácio ESB, Cantalice JRB, Nacif PGS, Araujo QR, Barreto AC. Quantificação da erosão em pastagem com diferentes declives na microbacia do Ribeirão Salomea. Revista Brasileira de Engenharia Agrícola e Ambiental. 2007;11(4):355-60. doi:10.1590/S141543662007000400002

Luciano RV, Bertol I, Barbosa FT, Vázquez EV, Fabian EL. Perdas de água e solo por erosão hídrica em duas direções de semeadura de aveia e ervilhaca. Revista Brasileira de Ciência do Solo. 2009;33(3):669-76. doi: 10.1590/S0100-06832009000300019

Magro BA, Dieckow J, Reissmann CB. Tillage systems to reduce soil, water and nutrient losses in Eucalyptus forest area, Southern Brazil. In: Horodnic SA, Duduman ML, Palaghianu C, eds. International Conference - Integrated Management of Environmental Resources (Booklet of Abstract); 2011; României. Suceava: Stefan cel mare; 2012. p. 45-46.

Oliveira LC, Bertol I, Campos ML, Mecabô Junior J. Erosão hídrica em plantio de pinus, em estrada florestal e em campo nativo. Revista Floresta. 2014;44(2):23948. doi: $10.5380 /$ rf.v44i2.31373

Padilha J, Bertol I, Magro BA, Bagio B, Marioti $\mathrm{J}$, Ramos JC. Water erosion under three tillage methods in a cultivation of Eucaliptus benthamii. Revista Árvore. 2017;41(6):1-9. doi:10.1590/180690882017000600006

Pires LS, Silva MLN, Curi N, Leite FP, Brito LF. Erosão hídrica pós-plantio em florestas de eucalipto na região centro-leste de Minas Gerais. Pesquisa
Agropecuária Brasileira. 2006;41(4):687-95. doi: 10.1590/S0100-204X2006000400021

Schick J, Bertol I, Cogo NP, Paz González A. Erosivity of rainfall in Lages, Santa Catarina, Brazil. Revista Brasileira de Ciência do Solo. 2014;38(6):1890-905. doi:10.1590/S0100-06832014000600024

Schick J, Bertol I, Barbosa FT, Miquelluti DJ, Cogo NP. Water Erosion in a Long-Term Soil Management Experiment with a Humic Cambisol. Revista Brasileira de Ciência do Solo. 2017;41:01-13. doi:10.1590/18069657rbcs20160383

Sharpley AN, Reed LW, Simmons DK. Relationships between available soil $\mathrm{P}$ forms and their role in water quality modeling. Oklahoma State University. Agnc. Exp. Stn. Bull; 1982. 157 p.

Silva FAA, Azevedo CAV. The Assistat Software version 7.7 and its use in the analysis of experimental data. African Journal of Agricultural Research. 2016;11(39):3733-40. doi:10.5897/AJAR2016.11522

Soil Survey Staff. Keys to soil taxonomy. 12th ed. Washington: United States Departament of Agriculture, Natural Resources Conservation Service; 2014. 360 p.

Sun D, Zhang W, Lin Y, Liu Z, Shen W, Zhou L, et al. Soil erosion and water retention varies with plantation type and age. Forest Ecology and Management. 2018;422:1-10. doi:10.1016/j.foreco.2018.03.048

Tedesco MJ, Gianello C, Bissani ca, Bohnen H, Volkweiss SJ. Análise de solo, plantas e outros materiais. 2.ed. rev. e ampL. PORTO ALEGRE: Departamento de Solos da Universidade Federal do Rio Grande do Sul; 1995. 174 P.

Wischmeier WH, Smith DD. Predicting rainfall erosion losses: a guide to conservation planning. Washington: USDA, (Agricultural Handbook, 537); 1978. 58 p. 